Article

\title{
Ontogenic Development of Digestive Enzymes in Mealworm Larvae (Tenebrio molitor) and Their Suitable Harvesting Time for Use as Fish Feed
}

\author{
Somrak Rodjaroen ${ }^{1}$, Karun Thongprajukaew ${ }^{2, *(1)}$, Puridet Khongmuang ${ }^{1}$, Saowalak Malawa ${ }^{2}$, \\ Kimhun Tuntikawinwong ${ }^{3}$ and Suktianchai Saekhow ${ }^{2}$ \\ 1 Department of Agriculture, Faculty of Science and Technology, Nakhon Si Thammarat Rajabhat University, \\ Nakhon Si Thammarat 80280, Thailand; somrak_rod@nstru.ac.th (S.R.); Poopooridet@gmail.com (P.K.) \\ 2 Department of Applied Science, Faculty of Science, Prince of Songkla University, Songkhla 90112, Thailand; \\ saowalak4866@gmail.com (S.M.); chaung_17@hotmail.com (S.S.) \\ 3 Hatyaiwittayalai School, Songkhla 90110, Thailand; mingzapingin@gmail.com \\ * Correspondence: karun.t@psu.ac.th; Tel.: +66-7428-8561
}

Received: 18 May 2020; Accepted: 15 June 2020; Published: 26 June 2020

check for updates

\begin{abstract}
Mealworm larvae (Tenebrio molitor) are edible insects consumed in feed and food. In the current study, the optimal harvesting time of mealworm larvae for use as aquafeed was investigated during the ages of 30-90 days after hatching (DAH). Development of digestive enzymes, proximate composition, and in vitro protein digestibility using digestive enzymes from African catfish (Clarias gariepinus) and Nile tilapia (Oreochromis niloticus), were used as criteria. The specific activities of pepsin and trypsin significantly decreased with age $(p<0.05)$ from the first harvesting time until 50 and $45 \mathrm{DAH}$, respectively, while steadiness in these enzyme activities was observed onwards. Chymotrypsin specific activity appeared constant across all harvesting times. The specific activity of amylase significantly decreased in the later stages of development, while cellulase exhibited a different pattern suggesting it has a major role in dietary fiber utilization relative to starch. Regarding proximate compositions of the mealworm larvae, the moisture and ash contents decreased significantly with age, while the protein content exhibited the opposite trend with the highest contents from 60 to 90 DAH. Crude lipid was generally fairly constant, but its lowest value was observed in the earliest stage. In vitro protein digestibility was not significantly different across all harvesting times for both fish species, except for the significantly decreased digestibility value at 65 DAH relative to 30 and 35 DAH for Nile tilapia. However, based on the economic benefits of time for growth increment and proximate chemical composition, approximately $60 \mathrm{DAH}$ is proposed as suitable for harvesting mealworm larvae to be used in fish feed.
\end{abstract}

Keywords: economic fish; harvesting time; in vitro digestibility; live feed; proximate composition

\section{Introduction}

Mealworm larvae (Tenebrio molitor) are edible insects consumed by people in many Asian countries, particularly in Southeast Asia [1]. They are generally found as street food alongside other edible insects, and they can be applied in making a healthy snack food. Moreover, they are typically used as live feed for pets and zoo animals, including birds, reptiles, small mammals, amphibians, and fish, and they can be used in canned, dried or powdered forms [2,3]. For aquatic animals, mealworm larvae have been used to feed various species, such as African catfish, Clarias gariepinus [4]; Atlantic salmon, Salmo salar [5]; blackspot seabream, Pagellus bogaraveo [6]; gilthead sea bream, Sparus aurata [7]; Nile tilapia, Oreochromis niloticus [8]; and red sea bream, Pagrus major [9]. Therefore, mealworm larvae have received growing interest in the list of potential protein sources for food and feed. 
The lifespan of mealworm beetles varies from 280 to 630 days, but the matured larval stage is typically reached 3-4 months after hatching at $18-20{ }^{\circ} \mathrm{C}$ [3]. These time profiles, as well as the nutritive values, also vary by the types of feed [3]. Therefore, juvenile hormones can be added to the food to prevent the molting of the larvae into adults, prolonging the harvesting time, as well as achieving higher weight and length of the larvae [10]. However, across a wide range of larval stages, nutritional information is unavailable for use as a criterion in selecting a suitable harvesting time range. Ontogenic development has been studied to understand the physiological changes and gut functions related to the growth and development of reared animal species. Across various studies, digestive enzymes are typically investigated since they are associated with nutritional status and feeding habits [11-15]. However, only limited information is available regarding the development of digestive enzymes in insects, in the literature reviewed.

In vitro digestibility (IVD) technique has been used to screen feedstuff or feed for animal rearing [15-17]. In terms of protein utilization, this technique detects the liberation of amino acids after proteolytic digestion. Therefore, this current study aimed to describe the ontogenic development of digestive enzymes in mealworm larvae, and we also used the IVD technique, proximate chemical composition, and growth performance as criteria for selecting a suitable harvesting time range for mealworm larvae. Findings from the current study provide basic knowledge of nutritional and physiological changes across a wide range of mealworm larval stages and can serve as practical guidelines for preparing mealworm larvae as fish feed.

\section{Materials and Methods}

Preparation, rearing and harvesting of all animals in the current study conformed to the "Ethical Principles and Guidelines for the Use of Animals for Scientific Purposes", National Research Council, Thailand (Application No. U1-06514-2560). Ten-day-old mealworm larvae were purchased from a private farm in the Nakhon Si Thammarat province of Thailand. They were reared in three plastic containers ( $30 \mathrm{~cm}$ width $\times 40 \mathrm{~cm}$ length $\times 10 \mathrm{~cm}$ height) containing $1 \mathrm{~kg}$ of wheat bran each. Two equal pieces of a ripe banana (Musa acuminata $\times$ Musa balbisiana) were placed on wheat bran to serve as a source of water and additives. The mealworm larvae were reared at a stocking density of 300 individuals per container, under a natural diurnal cycle (12-h dark/12-h light). Feces and dead mealworm larvae were removed from the container, and then new wheat bran was added to maintain $1 \mathrm{~kg}$ per container. The mealworm larvae were harvested at 30, 35, 40, 45, 50, 55, 60, 65, 70, 75, 80, 85 and 90 days after hatching (DAH). They were fasted for $12 \mathrm{~h}$ prior to sampling. All the samples were packed in polyethylene bags and chilled on ice for $30 \mathrm{~min}$. At each harvesting time, twenty mealworm larvae were sampled while ten mealworm larvae $(n=10$ per container) were weighed on a digital microbalance (Ohaus AR2140; Ohaus Corp., Parsippany, NJ, USA), and their lengths were measured to the nearest $0.01 \mathrm{~mm}$ using a digital Vernier caliper (Mitutoyo-500; Mitutoyo Corp., Kanagawa, Japan).

Undesirable contamination was removed carefully from the mealworm larvae, and then they were soaked in $5 \mathrm{mg} \mathrm{L}^{-1}$ of $\mathrm{KMnO}_{4}$ for $30 \mathrm{~min}$ [18,19], rinsed with distilled water three times, and filtered to remove the water. The whole bodies of the mealworm larvae were homogenized in cold $0.2 \mathrm{M}$ phosphate buffer ( $\mathrm{pH} 8,1: 3 \mathrm{w} / \mathrm{v}$ ) using a micro-homogenizer (THP-220; Omni International, Kennesaw, GA, USA). The homogenate was centrifuged at $15,000 \times g$ for $30 \mathrm{~min}$ at $4{ }^{\circ} \mathrm{C}$, and then the supernatant was collected, aliquoted, and kept at $-20{ }^{\circ} \mathrm{C}$ until use. The concentration of protein in the crude enzyme extract was assayed using the method of Lowry et al. [20], which used bovine serum albumin as standard protein. The concentration of soluble proteins $\left(\mathrm{mg} \mathrm{mL}^{-1}\right)$ was used to quantify the enzyme-specific activities ( $\mathrm{U}$ mg protein ${ }^{-1}$ ). All assays were performed within one month after extraction.

Pepsin activity was determined based on the method of Worthington [21] using hemoglobin as the substrate. The assay conditions were set at $\mathrm{pH} 2$ and $30^{\circ} \mathrm{C}$ [22]. One unit (U) of pepsin activity was defined by an increase of $1.0 \mathrm{in}$ absorbance at $280 \mathrm{~nm}$. The trypsin and chymotrypsin activities were assayed according to Rungruangsak-Torrissen et al. [23], using $N$-benzoyl-L-Arg- $p$-nitroanilide 
and $N$-succinyl-Ala-Ala-Pro-Phe- $p$-nitroanilide as the substrates, respectively. The assay conditions were $\mathrm{pH} 8.5$ and $55^{\circ} \mathrm{C}$ [24], and $\mathrm{pH} 9.5$ and $51^{\circ} \mathrm{C}$ [12], for the respective enzymes. The linear response range to $p$-nitroanilide at $410 \mathrm{~nm}$ was used to quantify the activities of both enzymes. The amylase activity was determined based on the method of Bernfeld [25], using soluble starch as the substrate, in comparison to a maltose standard curve at $540 \mathrm{~nm}$. The assay conditions were $\mathrm{pH} 5.4$ and 25 ${ }^{\circ} \mathrm{C}$ [13]. Cellulase activity was determined according to the method of Mendels and Weber [26], using carboxymethylcellulose as substrate, in comparison to a glucose standard curve at $540 \mathrm{~nm}$. The assay conditions were $\mathrm{pH} 8$ and $30^{\circ} \mathrm{C}$ [15]. One unit activity for all the digestive enzymes, except for pepsin, was defined as the amount that catalyzed the conversion of $1 \mu \mathrm{mol}$ of substrate per minute.

Whole larval mealworm carcasses ( $n=3$ pooled sample per treatment) were minced and analyzed for moisture and ash contents according to standard methods of the AOAC [27]. Crude protein was determined by the method of Rungruangsak-Torrissen [28] after extracting it with TRIzol ${ }^{\mathrm{TM}}$ reagent. Crude lipid was determined by extracting dried mealworm larval samples with ethyl acetate for $2 \mathrm{~h}$ in a rotary mixer, as described in Supannapong et al. [29]. All values were expressed on a wet weight basis.

For the IVD test, thirty Nile tilapia $(1.39 \pm 0.28 \mathrm{~g}$ body weight $)$ and African catfish $(5.45 \pm 0.24 \mathrm{~g}$ body weight) were purchased from a private farm in Songkhla province of Thailand. The fish were fed a commercial diet containing 18 and 25\% crude protein (Charoen Pokphand Foods PCL., Bangkok, Thailand), respectively, and they were fasted for $12 \mathrm{~h}$ prior to sampling. The fish were sacrificed by chilling in ice, and only the intestine was carefully removed, weighed, and then used for digestive enzyme extraction. Three pooled intestinal samples (ten fish per sample) were extracted in $0.2 \mathrm{M}$ $\mathrm{Na}_{2} \mathrm{HPO}_{4}-\mathrm{NaH}_{2} \mathrm{PO}_{4}$ buffer ( $\mathrm{pH}$ 8) at a ratio of 1: $6(w / v)$, using a micro-homogenizer (THP-220; Omni International, Kennesaw GA, USA). Centrifugation was performed at $15,000 \times g$ for $30 \mathrm{~min}$ at $4{ }^{\circ} \mathrm{C}$ prior to collecting the supernatant. The aliquots were kept at $-20^{\circ} \mathrm{C}$ until used for the IVD assay.

Fresh mealworm larvae were freeze-dried for $24 \mathrm{~h}$ using a freeze dryer (Flexidry; SP Scientific, Warminster, PA, USA) to eliminate moisture, and then they were minced to a homogeneous powder. The crude digestive enzymes from fish were dialyzed overnight against the extraction buffer. The in vitro protein digestibility procedure was performed as described by Thongprajukaew et al. [30]. The reaction mixtures contained $5 \mathrm{mg}$ freeze-dried mealworm larvae powder, $50 \mu \mathrm{L}$ of $0.5 \%$ chloramphenicol, and $125 \mu \mathrm{L}$ crude enzyme extract from the fish. Ten milliliters of $50 \mathrm{mM} \mathrm{Na} 2 \mathrm{HPO}_{4}-\mathrm{NaH}_{2} \mathrm{PO}_{4}$ buffer ( $\mathrm{pH}$ 8.2) was added to perform the alkaline condition, contributing the near-optimal $\mathrm{pH}$ for digesting by fish trypsin. These mixtures were incubated at $30^{\circ} \mathrm{C}$ under $200 \mathrm{rpm}$ agitation for $24 \mathrm{~h}$, against blank samples in which the enzyme volumes were replaced by extraction buffer. This condition provides a linear range of digested products ( $D L$-alanine) after performing substrate: enzyme ratio (200: $1 \mathrm{w} / \mathrm{v})$ for $24 \mathrm{~h}$. The reaction was terminated by boiling at $100{ }^{\circ} \mathrm{C}$ for $10 \mathrm{~min}$ and then cooled down at room temperature for $30 \mathrm{~min}$. The liberated amino acids in the digested solution were determined based on the trinitrobenzene sulfonic (TNBS) acid method, as described by Rungruangsak-Torrissen et al. [31]. The reaction contained $200 \mu \mathrm{L}$ of the digested solution, $2 \mathrm{~mL}$ of $50 \mathrm{mM} \mathrm{Na} 2 \mathrm{HPO}_{4}-\mathrm{NaH}_{2} \mathrm{PO}_{4}$ buffer (pH 8.2), and $1 \mathrm{~mL}$ of $0.1 \%$ TNBS. These mixtures were incubated in the dark at $60{ }^{\circ} \mathrm{C}$ for $1 \mathrm{~h}$ and then stopped by adding $1 \mathrm{~mL}$ of $1 \mathrm{M} \mathrm{HCl}$. The colorimetric detection was measured spectrophotometrically at $420 \mathrm{~nm}$ against a linear range of standard $D L$-alanine. Trypsin activity in dialyzed crude enzyme extract from triplicate samples was analyzed [23] before standardizing the digestibility value (500 U for Nile tilapia and African catfish). The IVD of protein was expressed as $\mu \mathrm{mol} D L$-alanine equivalent g mealworm larvae ${ }^{-1}$.

The experiment followed a completely randomized design (13 treatments $\times 3$ replications). All the data were analyzed using the Statistical Package for Social Sciences, Version 14 (SPSS Inc., Chicago, IL, USA) and were reported as mean \pm standard error of the mean (SEM). The normality and homogeneity of variance were checked. Means were compared using One-Way ANOVA, and differences were statistically analyzed with Duncan's multiple range test and regarded as significant at $p<0.05$ in all statistical analyses. Relationships between each pair of digestive enzymes were assessed from Pearson correlations. 


\section{Results}

\subsection{Changes in Weight and Length across Studied Period}

The length and weight of the mealworm larvae increased progressively from 30 DAH on to 50 DAH and to $55 \mathrm{DAH}$, respectively (Figure 1a). A stable pattern of length was observed previously in mealworm larvae relative to their body weight. Both performance measures as functions of time (in DAH) were well fit by sixth-order polynomials, $y=\left(-6 \times 10^{-10}\right) x^{6}+\left(2 \times 10^{-7}\right) x^{5}-\left(3 \times 10^{-5}\right) x^{4}+$ $0.002 x^{3}-0.106 x^{2}+2.375 x-20.44$ and $y=\left(-2 \times 10^{-7}\right) x^{6}+\left(6 \times 10^{-5}\right)-0.007 x^{4}+0.569 x^{3}-22.16 x^{2}+$ $449.2 x-3697$, respectively. The larval body lengths and weights at 30 to $90 \mathrm{DAH}$ are illustrated in Figure $1 b$.

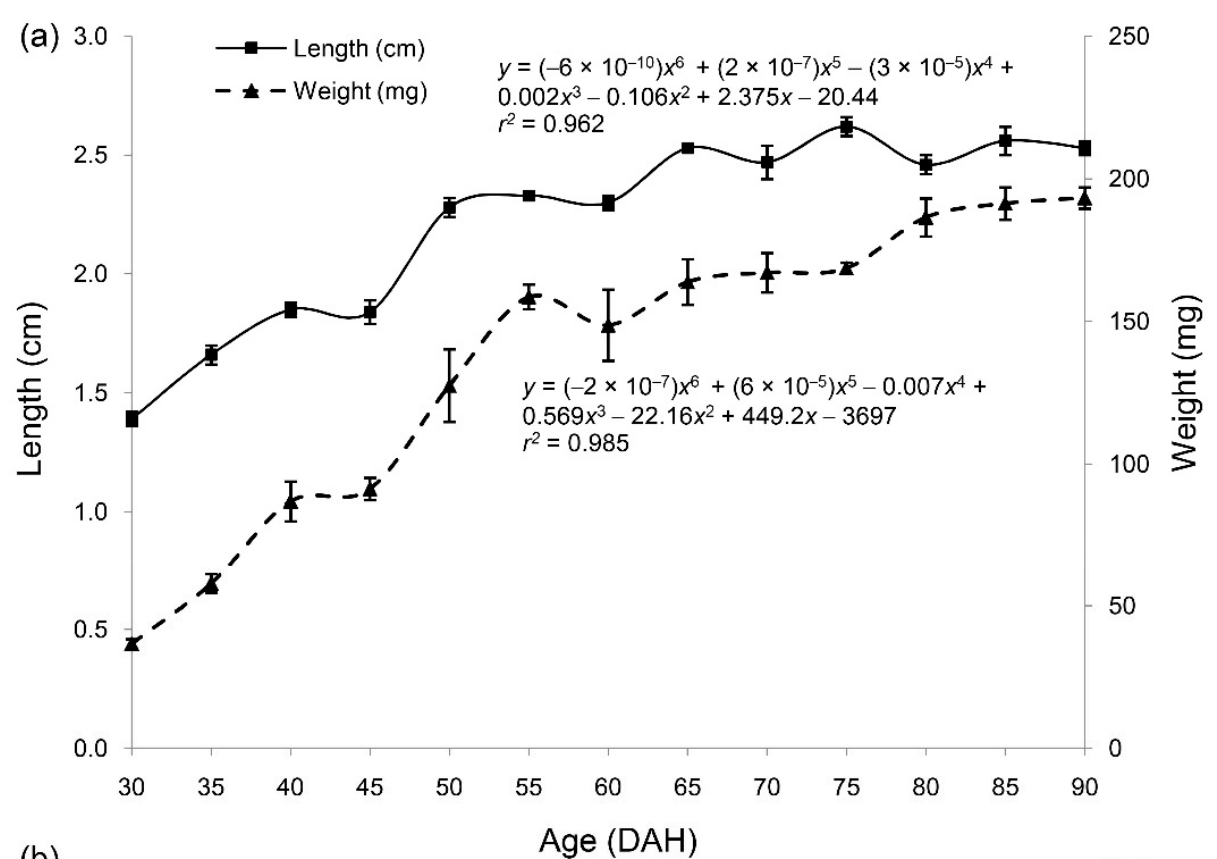

(b)

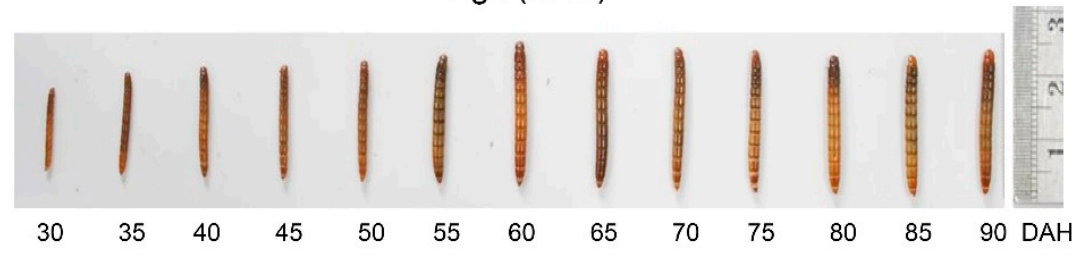

Figure 1. Ontogenic changes in body weight and length of mealworm larvae (a). Data are expressed as mean \pm SEM from triplicate measurements $(n=30$ per sampling time). Larval body lengths at different harvesting times $(\mathbf{b})$. DAH stands for days after hatching.

\subsection{Ontogenic Development of Digestive Enzymes}

The specific activities of pepsin (Figure 2a) and trypsin (Figure 2b) significantly decreased with age $(p<0.05)$. High specific activity of both enzymes was observed from the first sampling time until 45 and $40 \mathrm{DAH}$, respectively, and then a steady level was maintained until $90 \mathrm{DAH}$. On the other hand, chymotrypsin specific activity appeared constant across all sampled times (Figure 2c). Relative to chymotrypsin, the specific activity of amylase exhibited a rather similar pattern, but with significantly decreased activity from 85 to 90 DAH (Figure 2d). For cellulase, the specific activity was lowest at $30 \mathrm{DAH}$, and then it was maintained at a steady level until the last sampling time (Figure 2e). Based on the Pearson correlation analysis, a significant relationship across all stages of mealworm larvae was observed between pepsin and trypsin and between pepsin and amylase, while in other pairs, the specific activities did not significantly correlate (Table 1). 

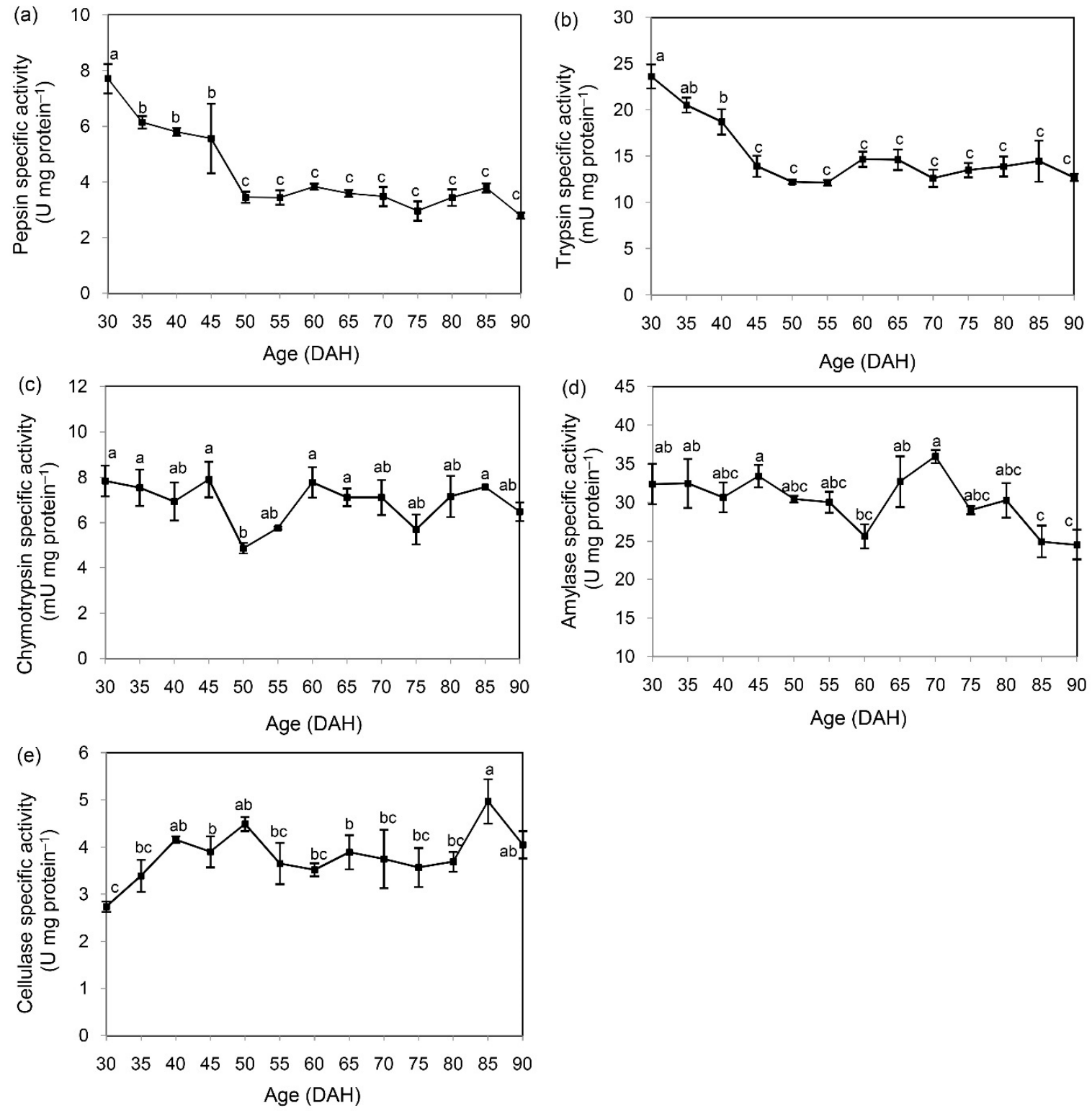

Figure 2. Ontogenic changes in specific activities of pepsin (a), trypsin (b), chymotrypsin (c), amylase (d), and cellulase (e) in mealworm larvae. Data are expressed as mean \pm SEM from triplicate measurements. Significant differences between treatments are indicated by different superscripts $(p<0.05)$. DAH stands for days after hatching.

Table 1. Pearson correlation coefficients $(r)$ of time profiles of digestive enzyme specific activities, detected in mealworm larvae $(n=39)$.

\begin{tabular}{cccccc}
\hline Digestive Enzyme & Pepsin & Trypsin & Chymotrypsin & Amylase & Cellulase \\
\hline Pepsin & 1 & & & & \\
Trypsin & $0.761^{* *}$ & 1 & & & \\
Chymotrypsin & 0.199 & 0.205 & 1 & 1 & \\
Amylase & $0.417^{* *}$ & 0.284 & 0.103 & 0.187 & 1 \\
Cellulase & -0.199 & -0.159 & 0.244 &
\end{tabular}




\subsection{Chemical Composition of Mealworm Larvae}

Moisture and ash contents decreased significantly with the age of the mealworm larvae, while the protein content exhibited the opposite trend and remained high from 60 to 90 DAH. Crude lipid was generally similar across all stages of mealworm larvae, with the lowest value observed in the youngest stage (Table 2).

Table 2. Proximate chemical compositions (in \% of fresh weight) of mealworm larvae at each sampling time.

\begin{tabular}{|c|c|c|c|c|}
\hline Age (DAH) & Moisture & Crude Protein & Crude Lipid & Ash \\
\hline 30 & $64.37 \pm 0.83^{a}$ & $17.43 \pm 3.34^{\mathrm{e}}$ & $9.85 \pm 0.17^{\mathrm{e}}$ & $1.96 \pm 0.06^{\mathrm{a}, \mathrm{b}}$ \\
\hline 35 & $62.64 \pm 1.24^{\mathrm{a}, \mathrm{b}}$ & $17.90 \pm 1.82^{\mathrm{d}, \mathrm{e}}$ & $10.64 \pm 1.21^{\mathrm{d}, \mathrm{e}}$ & $2.37 \pm 0.55^{\mathrm{a}}$ \\
\hline 40 & $60.89 \pm 0.24^{b, c}$ & $19.14 \pm 0.65^{\mathrm{d}, \mathrm{e}}$ & $16.19 \pm 0.98^{a, b, c}$ & $2.37 \pm 0.28^{a}$ \\
\hline 45 & $59.03 \pm 0.17^{c, d}$ & $20.70 \pm 1.04^{c, d, e}$ & $17.92 \pm 2.53^{\mathrm{a}}$ & $1.82 \pm 0.08^{b, c}$ \\
\hline 50 & $58.35 \pm 0.46^{\mathrm{d}, \mathrm{e}}$ & $19.47 \pm 0.61^{\mathrm{d}, \mathrm{e}}$ & $15.51 \pm 1.43^{\mathrm{a}, \mathrm{b}, \mathrm{c}, \mathrm{d}}$ & $1.35 \pm 0.11^{\mathrm{c}}$ \\
\hline 55 & $56.56 \pm 0.44^{\mathrm{e}, \mathrm{f}}$ & $20.86 \pm 0.92^{c, d, e}$ & $14.02 \pm 0.70^{\mathrm{a}, \mathrm{b}, \mathrm{c}, \mathrm{d}}$ & $1.58 \pm 0.08^{b, c}$ \\
\hline 60 & $54.83 \pm 0.42^{\mathrm{f}, \mathrm{g}}$ & $26.79 \pm 0.45^{\mathrm{a}, \mathrm{b}}$ & $14.00 \pm 2.18^{\mathrm{a}, \mathrm{b}, \mathrm{c}, \mathrm{d}, \mathrm{e}}$ & $1.65 \pm 0.04^{b, c}$ \\
\hline 65 & $55.80 \pm 1.38^{\mathrm{f}, \mathrm{g}}$ & $24.38 \pm 1.91^{\mathrm{a}, \mathrm{b}, \mathrm{c}}$ & $15.12 \pm 0.75^{\mathrm{a}, \mathrm{b}, \mathrm{c}, \mathrm{d}}$ & $1.43 \pm 0.09^{c}$ \\
\hline 70 & $54.74 \pm 1.41^{\mathrm{f}, \mathrm{g}}$ & $25.85 \pm 2.25^{\mathrm{a}, \mathrm{b}, \mathrm{c}}$ & $17.32 \pm 0.50^{\mathrm{a}, \mathrm{b}}$ & $1.70 \pm 0.10^{b, c}$ \\
\hline 75 & $55.51 \pm 0.79^{\mathrm{f}, \mathrm{g}}$ & $29.80 \pm 1.05^{\mathrm{a}}$ & $13.64 \pm 2.07^{\mathrm{a}, \mathrm{b}, \mathrm{c}, \mathrm{d}}$ & $1.59 \pm 0.05^{b, c}$ \\
\hline 80 & $53.40 \pm 0.43 \mathrm{~g}$ & $30.49 \pm 2.76^{a}$ & $14.22 \pm 0.20^{\mathrm{a}, \mathrm{b}, \mathrm{c}, \mathrm{d}, \mathrm{e}}$ & $1.60 \pm 0.11^{b, c}$ \\
\hline 85 & $55.74 \pm 0.32^{\mathrm{f}, \mathrm{g}}$ & $26.08 \pm 1.45^{\mathrm{a}, \mathrm{b}, \mathrm{c}}$ & $12.87 \pm 0.16^{b, c, d}$ & $1.36 \pm 0.14^{\mathrm{c}}$ \\
\hline 90 & $55.27 \pm 0.69^{\mathrm{f}, \mathrm{g}}$ & $29.05 \pm 0.97^{a}$ & $18.03 \pm 2.28^{a}$ & $1.73 \pm 0.06^{b, c}$ \\
\hline$p$-value & $<0.001$ & $<0.001$ & 0.007 & 0.002 \\
\hline
\end{tabular}

Note: DAH, days after hatching. Data are expressed as mean \pm SEM $(n=3)$. Differences between means were tested with Duncan's multiple range test. Different superscripts in the same column indicate a significant difference $(p<$ $0.05)$.

\subsection{In Vitro Protein Digestibility Using Digestive Enzymes from Two Fish Species}

In vitro digestibility (IVD) of protein, using digestive enzymes from Nile tilapia was generally similar across thirteen sampled times, but significantly decreased IVD was observed at 65 DAH relative to 30 and 35 DAH (Figure 3a). There were no effects of DAH on IVD for catfish (Figure 3b). 

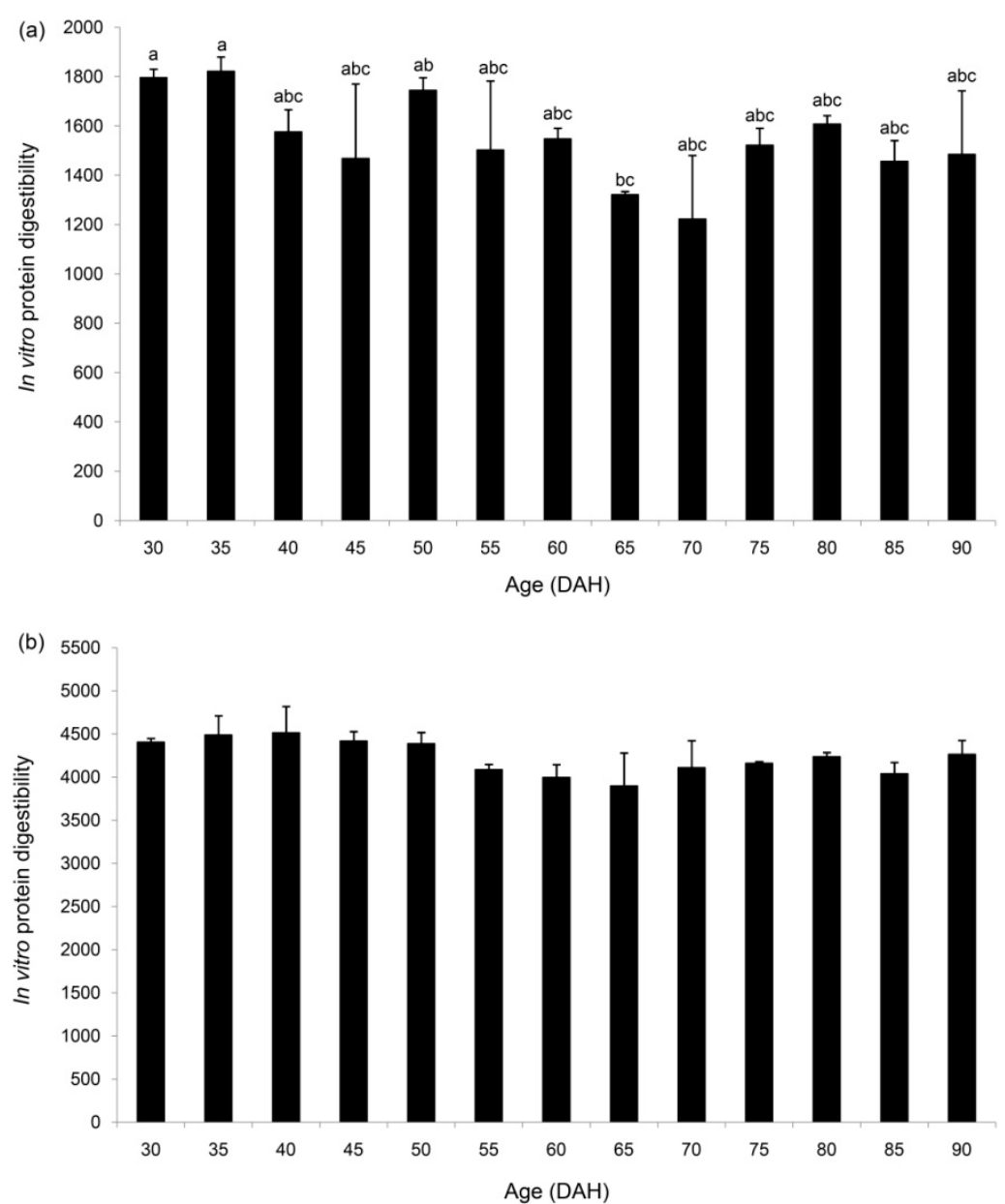

Figure 3. In vitro digestibility of protein ( $\mu \mathrm{mol} D L$-alanine equivalent $\mathrm{g}$ mealworm larvae ${ }^{-1}$ ) in mealworm larvae using digestive enzyme extract from Nile tilapia (a), and from African catfish (b). Data are expressed as mean \pm SEM from triplicate measurements. Significant differences between treatments are indicated by different superscripts $(p<0.05)$. DAH stands for days after hatching.

\section{Discussion}

The experiment was terminated at $90 \mathrm{DAH}$ since some mealworm larvae were transitioning into the pupal stage. Weight and length of mealworm larvae fitted the polynomial regression models well, providing correlations of $0.962-0.985$. These morphometric parameters were relatively constant from 65 and $80 \mathrm{DAH}$, respectively. These findings indicate that the growth rate was slower than linear, as the larvae spend their time eating and growing for the next transformation, concurrently with molting. This polynomial growth pattern has also been reported in the same species by Özsoy [32], as well as for various other insect species, such as melon thrips (Thrips palmi), soybean looper (Pseudoplusia includens), Mexican bean beetle (Epilachna varivestis), and velvetbean caterpillar (Ancarsia gemmatalis) [33,34].

Fly enzymes appear functionally to be similar to vertebrate enzymes [14]. In the current study, the ontogenic development has significant effects on specific activities of protein-digesting enzymes (pepsin-like, trypsin, and chymotrypsin) in mealworm larvae. Generally, pepsin and trypsin are major digestive enzymes in vertebrates, contributing to protein digestion in the stomach and intestine, respectively. However, the pepsin-like activity might occur due to substrate hydrolysis (hemoglobin) by other enzymes, such as cathepsin D, which is functionally equivalent and structurally similar to pepsin [35]. Specific inhibitor assays and the substrate-SDS PAGE procedure could be used to confirm the findings from this current study. Significant decreases in trypsin and pepsin-like activities occurred around $45 \mathrm{DAH}$ and were maintained until the end of sampling, indicating maturation of 
gut functionality in terms of protein digestion, and also suggesting a shift in the feeding habits with maturation. In addition, the abrupt decreases in both enzyme activities with DAH suggest that protein intake plays a minor role in the older stages of mealworm larvae, so that feed sources low in protein might be appropriate. This hypothesis is also corroborated by the significant positive relationship $(r=0.761, p<0.01, n=39)$ between these enzymes throughout sampling. As regards chymotrypsin, this enzyme is activated by trypsin. Its relatively constant activity suggests a minor role of this enzyme in digesting protein, relative to pepsin-like enzymes or trypsin.

Physiological changes between protein and carbohydrate catabolism occur concurrently, as indicated by the significant positive relationship $(r=0.417, p<0.01, n=39)$ between the specific activities of pepsin and amylase. Over the sampled times, significant changes in carbohydrate-digesting enzymes (amylase and cellulase) were observed 10 days prior to the end of sampling, as compared to the youngest stage. These findings suggest that sources high in cellulosic materials might be more suitable than starch-based materials. This matches well with the proximate composition of wheat bran from the current study and the typical feed for this species (cereal bran, wheat flour, oat flour, or maize flour) supplemented with protein sources such as soybean flour, skimmed milk powder, or yeast $[3,36]$.

The chemical composition of mealworm larvae is highly variable and influenced by the feed [3]. However, the composition of mealworm larvae based on the current study was similar and within the ranges in prior publications [1,10,37-42]. Fresh mealworm larvae contain approximately $60 \%$ moisture and high amounts of protein and lipid. Decreased moisture and ash contents with age might be due to the accumulation of protein, as well as the replacement of these constituents by chitin and chitosan, making mealworm larvae suitable as sources of oligosaccharides [43]. Not only a good amount of protein but also a good profile of amino acids has been reported [3]. Crude lipid was generally similar, but the lowest value was observed in the youngest stage. A low amount of lipid accumulation is reasonable for the youngest stage that initially exhibited the reserve. This finding is in agreement with the increased size of fat droplets within the trophocyte, as well as lipogenesis, following body weight increases [44]. However, the relatively high lipid content of dried mealworm larvae from the current study, as well as generally high level of unsaturated fatty acids, makes them susceptible to oxidation if not treated with an antioxidant [10,38].

IVD values depend on the quality of feedstuffs rather than their quantity $[30,45,46]$. IVD has been used to screen for suitable feedstuffs to feed fish. This technique is based on the digestion of protein by trypsin under alkaline conditions, mimicking the intestinal $\mathrm{pH}$ of fish [31,47]. The same technique from the current study has also been applied in feed development for various aquatic species, such as Atlantic salmon [28], Siamese fighting fish (Betta splendens) [30], Nile tilapia [46], silver barb (Barbonymus gonionotus) [46], and freshwater pearl mussel (Hyriopsis (Hyriopsis) bialatus) [29,48]. Based on our investigations, similar protein digestibility across all stages of mealworm larvae was observed, using digestive enzymes from Nile tilapia and African catfish. All the IVD values did not correlate with the proximate composition of protein in mealworm larvae. Comparing the IVD values was unsuitable for both fish species because of differences in nutrient digestibility, ages, genetics, feeding biology, and rearing conditions. In addition, limited information obtained from an assay performed in the current study may be caused by differences in digestive physiology between fish species. However, this finding supports the use of mealworm larvae as fish feed over a wide range of rearing (from 30 to $90 \mathrm{DAH})$, since they show a high apparent digestibility coefficient. This makes them a potential alternative feed for Nile tilapia fingerlings relative to other insect meals evaluated, such as speckled cockroach (Nauphoeta cinerea) meal, superworm (Zophobas morio) larvae meal, Madagascar hissing cockroach (Gromphadorhina portentosa) meal, and Jamaican field cricket (Gryllus assimilis) meal [49].

\section{Conclusions}

Digestive enzymes in mealworm larvae were genetically programed across thirteen developmental stages since only one type of feed was used throughout the experiment. Of the five digestive enzymes studied, carbohydrate-digesting enzymes (cellulase and amylase) play a major role in utilizing nutrients 
relative to protein-digesting enzymes (pepsin, trypsin, and chymotrypsin). The proximate composition of the mealworm larvae varied with the developmental stage, with protein being the major constituent, which is why they could be an excellent source of protein. However, mealworm larvae are not suitable as the main feed ingredient due to their high amounts of lipids, mainly unsaturated fatty acids, but they could be used in a mixture of different insects to obtain an ideal nutritional medium [1,42]. For use as fish feed, harvesting times had no or only minor effects on the IVD, based on our study. This suggests that a wide range of times is suitable for harvesting mealworm larvae (from 30 to 90 DAH). However, approximately $60 \mathrm{DAH}$ is recommended due to the economic benefits of time for growth increment and proximate composition. Various factors can affect the validity or applicability of our findings including feed type and rearing conditions of the mealworm larvae. In addition, molting not only affects growth but also changes the components of the mealworm larvae before and after molting. Clarifying the relationships between molting and responsiveness of the digestive enzyme activities of the mealworm larvae, and/or the results of IVD should be of interest.

Author Contributions: Conceptualization, S.R. and K.T. (Karun Thongprajukaew); methodology, S.R., K.T. (Karun Thongprajukaew), P.K., S.M., K.T. (Kimhun Tuntikawinwong) and S.S.; formal analysis, S.R. and K.T. (Karun Thongprajukaew); investigation, S.R., K.T. (Karun Thongprajukaew), P.K., S.M., K.T. (Kimhun Tuntikawinwong) and S.S.; resources, S.R. and K.T. (Karun Thongprajukaew); data curation, K.T. (Karun Thongprajukaew); writing-original draft preparation, K.T. (Karun Thongprajukaew); writing-review and editing, S.R. and K.T. (Karun Thongprajukaew); supervision, K.T. (Karun Thongprajukaew); project administration, S.R. and K.T. (Karun Thongprajukaew); funding acquisition, S.R. and K.T. (Karun Thongprajukaew). All authors have read and agreed to the published version of the manuscript.

Funding: This research received no external funding.

Acknowledgments: The authors would like to thank the Publication Clinic, Research and Development Office, Prince of Songkla University, for advice in manuscript preparation.

Conflicts of Interest: The authors declare no conflict of interest.

\section{References}

1. Ghosh, S.; Lee, S.-M.; Jung, C.; Meyer-Rochow, V.B. Nutritional composition of five commercial edible insects in South Korea. J. Asia-Pac. Entomol. 2017, 20, 686-694. [CrossRef]

2. Aguilar-Miranda, E.D.; López, M.G.; Escamilla-Santana, C.; Barba de la Rosa, A.P. Characteristics of maize flour tortilla supplemented with ground Tenebrio molitor larvae. J. Agric. Food Chem. 2002, 50, $192-195$. [CrossRef] [PubMed]

3. Makker, H.P.S.; Tran, G.; Heuzé, V.; Ankers, P. State-of-the-art on use of insects as animal feed. Anim. Feed Sci. Technol. 2014, 197, 1-33. [CrossRef]

4. Ng, W.K.; Liew, F.L.; Ang, L.P.; Wong, K.W. Potential of mealworm (Tenebrio molitor) as an alternative protein source in practical diets for African catfish, Clarias gariepinus. Aquac. Res. 2001, 32, 273-280. [CrossRef]

5. Lock, E.R.; Arsiwalla, T.; Waagbø, R. Insect larvae meal as an alternative source of nutrients in the diet of Atlantic salmon (Salmo salar) postsmolt. Aquac. Nutr. 2016, 22, 1202-1213. [CrossRef]

6. Iaconisi, V.; Marono, S.; Parisi, G.; Gasco, L.; Genovese, L.; Maricchiolo, G.; Bovera, F.; Piccolo, G. Dietary inclusion of Tenebrio molitor larvae meal: Effects on growth performance and final quality treats of blackspot sea bream (Pagellus bogaraveo). Aquaculture 2017, 476, 49-58. [CrossRef]

7. Piccolo, G.; Iaconisi, V.; Marono, S.; Gasco, L.; Loponte, R.; Nizza, S.; Bovera, F.; Parisi, G. Effect of Tenebrio molitor larvae meal on growth performance, in vivo nutrients digestibility, somatic and marketable indexes of gilthead sea bream (Sparus aurata). Anim. Feed Sci. Technol. 2017, 226, 12-20. [CrossRef]

8. Sánchez-Muros, M.J.; DeHaro, C.; Sanz, A.; Trenzado, C.E.; Villareces, S.; Barroso, F.G. Nutritional evaluation of Tenebrio molitor meal as fishmeal substitute for tilapia (Oreochromis niloticus) diet. Aquac. Nutr. 2016, 22, 943-955. [CrossRef]

9. Ido, A.; Hashizume, A.; Ohta, T.; Takahashi, T. Replacement of fish meal by defatted yellow mealworm (Tenebrio molitor) larvae in diet improves growth performance and disease resistance in red seabream (Pagrus major). Animals 2019, 9, 100. [CrossRef]

10. Finke, M.D. Complete nutrient composition of commercially raised invertebrates used as food for insectivores. Zoo Biol. 2002, 21, 269-285. [CrossRef] 
11. Lovett, D.L.; Felder, D.L. Ontogenetic changes in enzyme distribution and midgut function in developmental stages of Penaeus setiferus (Crustacea, Decapoda, Penaeidae). Biol. Bull. 1990, 178, 160-174. [CrossRef]

12. Elpidina, E.N.; Tsybina, T.A.; Dunaevsky, Y.E.; Belozersky, M.A.; Zhuzhikov, D.P.; Oppert, B. A chymotrypsin-like proteinase from the midgut of Tenebrio molitor larvae. Biochimie 2005, 87, 771-779. [CrossRef] [PubMed]

13. Applebaum, S.W.; Jankovic, M.; Birk, Y. Studies on the midgut amylase activity of Tenebrio molitor L. larvae. J. Insect Physiol. 1961, 7, 100-108. [CrossRef]

14. Rivers, D.B.; Acca, G.; Fink, M.; Brogan, R.; Schoeffield, A. Spatial characterization of proteolytic enzyme activity in the foregut region of the adult necrophagous fry, Protophormai terraenovae. J. Insect Physiol. 2014, 67, 45-55. [CrossRef]

15. Chandang, P.; Thongprajukaew, K.; Chotimanothum, B.; Kovitvadhi, A.; Kovitvadhi, U.; Pakkong, P. The effects on in vitro digestibility from different developmental stages of silkworm larvae, Bombyx mori (Lepidoptera: Bombycidae) and position of mulberry leaves, Morus alba (Rosales: Moraceae). J. Asia-Pac. Entomol. 2017, 20, 1134-1139. [CrossRef]

16. Kovitvadhi, A.; Chundang, P.; Thongprajukaew, K.; Tirawattanawanich, C.; Srikachar, S.; Chotimanothum, B. Potential of insect meals as protein sources for meat-type ducks based on in vitro digestibility. Animals 2019, 9, 155. [CrossRef] [PubMed]

17. Marono, S.; Piccolo, G.; Loponte, R.; Di Meo, C.; Attia, Y.A.; Nizza, A.; Bovera, F. In vitro crude protein digestibility of Tenebrio molitor and Hermetia illucens insect meals and its correlation with chemical composition traits. Ital. J. Anim. Sci. 2015, 14, 338-343. [CrossRef]

18. Carpenter, J.W.; Mashima, T.Y.; Rupiper, D.J. Exotic Animal Formulary, 4th ed.; Elsevier: Amsterdam, The Netherlands, 2013; p. 46.

19. Noga, E.J. Fish. Disease: Diagnosis and Treatment, 2nd ed.; Wiley Blackwell: Ames, IA, USA, 2010; p. 410.

20. Lowry, O.H.; Rosenbrough, N.J.; Farr, A.L.; Randall, R.J. Protein measurement with the Folin phenol reagent. J. Biol. Chem. 1951, 193, 265-275. [PubMed]

21. Worthington, V. Worthington Enzyme Manual. Enzymes and Related Biochemicals; Worthington Chemical: Lakewood, NJ, USA, 1993; p. 399.

22. Houseman, J.G.; Downe, A.E.R. Cathepsin D-like activity in the posterior midgut of hemipteran insects. Comp. Biochem. Physiol. 1983, 75, 509-512. [CrossRef]

23. Rungruangsak-Torrissen, K.; Moss, R.; Andresen, L.H.; Berg, A.; Waagbo, R. Different expressions of trypsin and chymotrypsin in relation to growth in Atlantic salmon (Salmo salar L.). Fish. Physiol. Biochem. 2006, 32, 7-23. [CrossRef]

24. Tsybina, T.A.; Dunaevsky, Y.E.; Belozersky, M.A.; Zhuzhikov, D.P.; Oppert, B.; Elpidina, E.N. Digestive proteinases of yellow mealworm (Tenebrio molitor) larvae: Purification and characterization of a trypsin-like proteinase. Biochemistry 2005, 70, 300-305. [CrossRef]

25. Bernfeld, P. Enzymes of starch degradation and synthesis. Adv. Enzymol. 1951, 12, 379-428.

26. Mendels, M.; Weber, J. The product of cellulose in cellulase and their application. Adv. Chem. Ser. 1969, 95, 391-443.

27. AOAC. Official Method of Analysis of AOAC International; Association of Official Analytical Chemists: Arlington, VA, USA, 1990; pp. 69-84.

28. Rungruangsak-Torrissen, K. Digestive efficiency, growth and qualities of muscle and oocyte in Atlantic salmon (Salmo salar L.) fed on diets with krill meal as an alternative protein source. J. Food Biochem. 2007, 31, 509-540. [CrossRef]

29. Supannapong, P.; Pimsalee, T.; A-komol, T.; Engkagul, A.; Kovitvadhi, U.; Kovitvadhi, S.; Rungruangsak-Torrissen, K. Digestive enzymes and in vitro digestibility of different species of phytoplankton for culture of the freshwater pearl mussel, Hyriopsis (Hyriopsis) bialatus. Aquac. Int. 2008, 16, 437-453. [CrossRef]

30. Thongprajukaew, K.; Kovitvadhi, U.; Kovitvadhi, S.; Somsueb, P.; Rungruangsak-Torrissen, K. Effects of different modified diets on growth, digestive enzyme activities and muscle compositions in juvenile Siamese fighting fish (Betta splendens Regan, 1910). Aquaculture 2011, 322-323, 1-9. [CrossRef]

31. Rungruangsak-Torrissen, K.; Rustad, A.; Sunde, J.; Eiane, S.A.; Jensen, H.B.; Opstvedt, J.; Nygård, E.; Samuelsen, T.A.; Mundheim, H.; Luzzana, U.; et al. In vitro digestibility based on fish crude enzyme extract for prediction of feed quality in growth trials. J. Sci. Food Agric. 2002, 82, 644-654. [CrossRef] 
32. Özsoy, A.N. Modeling of development and water consumption of mealworm (Tenebrio molitor L., 1758) (Coleoptera: Tenebrionidae) larvae using nonlinear growth curves and polynomial functions. Turk. J. Entomol. 2019, 43, 253-262. [CrossRef]

33. Beanland, L.; Phelan, P.L.; Salminen, S. Micronutrient interactions on soybean growth and the developmental performance of three insect herbivores. Environ. Entomol. 2003, 32, 641-651. [CrossRef]

34. Yadav, R.; Chang, N.-T. Effects of temperature on the development and population growth of the melon thrips, Thripspalmi, on eggplant, Solanum melongena. J. Insect Sci. 2013, 14, 78.

35. Padilha, M.P.H.; Pimentel, A.C.; Ribeiro, A.F.; Terra, W.R. Sequence and function of lysosomal and digestive cathepsin D-like proteinases of Musca domestica midgut. Insect Biochem. Mol. Biol. 2009, 39, 782-791. [CrossRef] [PubMed]

36. Ramos-Elorduy, J.; Avila Gonzalez, E.; Rocha Hernandez, A.; Pino, J.M. Use of Tenebrio molitor (Coleoptera: Tenebrionidae) to recycle organic wastes and as feed for broiler chickens. J. Econ. Entomol. 2002, 95, 214-220. [CrossRef] [PubMed]

37. Barker, D.; Fitzpatrick, M.P.; Dierenfeld, E.S. Nutrient composition of selected whole invertebrates. Zoo Biol. 1998, 17, 123-134. [CrossRef]

38. Jones, L.D.; Cooper, R.W.; Harding, R.S. Composition of mealworm Tenebrio molitor larvae. J. Zoo Anim. Med. 1972, 3, 34-41. [CrossRef]

39. Paul, A.; Frederich, M.; Megido, R.C.; Alabi, T.; Malik, P.; Uyttenbroeck, R.; Francis, F.; Blecker, C.; Haubruge, E.; Lognay, G.; et al. Insect fatty acids: A comparison of lipids from three Orthopterans and Tenebrio molitor L. larvae. J. Asia-Pac. Entomol. 2017, 20, 337-340. [CrossRef]

40. Ravzanaadii, N.; Kim, S.H.; Choi, W.H.; Hong, S.J.; Kim, N.J. Nutritional value of mealworm, Tenebrio molitor as food source. Int. J. Ind. Entomol. 2012, 25, 93-98. [CrossRef]

41. Zhao, X.; Vázquez-Gutiérrez, J.L.; Johansson, D.P.; Landberg, R.; Langton, M. Yellow mealworm protein for food purposes-Extraction and functional properties. PLoS ONE 2016, 11, e0147791. [CrossRef]

42. Adámková, A.; Kouřimská, L.; Borkovcová, M.; Kulma, M.; Mlček, J. Nutritional values of edible coleoptera (Tenebrio molitor, Zophobas morio and Alphitobius diaperinus) reared in the Czech Republic. Potravin. Slovak. J. Food Sci. 2016, 10, 663-671.

43. Song, Y.S.; Kim, M.W.; Moon, C.; Seo, D.J.; Han, Y.S.; Jo, Y.H.; Noh, M.Y.; Park, Y.K.; Kim, S.A.; Kim, Y.W.; et al. Extraction of chitin and chitosan from larval exuvium and whole body of edible mealworm, Tenebrio molitor. Entomol. Res. 2018, 48, 227-233. [CrossRef]

44. Pascini, T.V.; Albeny, D.S.; Ramalho-Ortigão, M.; Vilela, E.F.; Serrão, J.E.; Martins, G.F. Changes in the fat body during the post-embryonic development of the predator Toxorhynchites theobaldi (Dyar \& Knab) (Diptera: Culicidae). Neotrop. Entomol. 2011, 40, 456-461.

45. Thongprajukaew, K.; Rodjaroen, S.; Tantikitti, C.; Kovitvadhi, U. Physicochemical modifications of dietary palm kernel meal affect growth and feed utilization of Nile tilapia (Oreochromis niloticus). Anim. Feed Sci. Technol. 2015, 202, 90-99. [CrossRef]

46. Chumwaengwapee, S.; Soontornchai, S.; Thongprajukaew, K. Improving chemical composition, physicochemical properties, and in vitro carbohydrate digestibility of fish coconut meal. ScienceAsia 2013, 39, 636-642. [CrossRef]

47. Bassompierre, M.; Ostenfeld, T.H.; McLean, E.; Rungruangsak-Torrissen, K. In vitro protein digestibility, and growth of Atlantic salmon with different trypsin isozymes. Aquac. Int. 1998, 6, 47-56. [CrossRef]

48. Areekijseree, M.; Engkagul, A.; Kovitvadhi, S.; Kovitvadhi, U.; Thongpan, A.; RungruangsakTorrissen, K. Development of digestive enzymes and in vitro digestibility of different species of phytoplankton for culture of early juveniles of the freshwater pearl mussel, Hyriopsis (Hyriopsis) bialatus Simpson, 1900. Invert. Reprod. Dev. 2006, 49, 255-262. [CrossRef]

49. Fontes, T.V.; Oliveira, K.R.B.; Almeida, I.L.G.; Orlando, T.M.; Rodrigues, P.B.; da Costa, D.V.; Rosa, P.V. Digestibility of insect meals for Nile tilapia fingerlings. Animals 2019, 9, 181. [CrossRef] [PubMed]

(C) 2020 by the authors. Licensee MDPI, Basel, Switzerland. This article is an open access article distributed under the terms and conditions of the Creative Commons Attribution (CC BY) license (http://creativecommons.org/licenses/by/4.0/). 